\title{
PENGARUH PENGGUNAAN ALAT PERAGA BERBANTUKAN KEARIFAN LOKAL TERHADAP HASIL BELAJAR SISWA KELAS VII DI MTS NEGERI 3 MATARAM
}

\author{
Julaiha ${ }^{1 *}$, Islahudin ${ }^{2}$, Johri Sabaryati ${ }^{3}$ \\ ${ }^{1 *}$ Mahasiswa Sarjana Progran Studi Pendidikan Fisika Universitas Muhammadiyah Mataram \\ ${ }^{283}$ Dosen Progran Studi Pendidikan Fisika Universitas Muhammadiyah Mataram \\ Corresponding author : \\ E-mail: (jehanjulaicha94@gmail.com)
}

Diterima 25 Oktober 2017, Disetujui 8 November 2017

\begin{abstract}
ABSTRAK
Penelitian ini merupakan penelitian eksperimen yang bertujuan untuk mengetahui pengaruh penggunaan alat peraga berbantukan kearifan lokal terhadap hasil belajar fisika siswa kelas VII MTs Negeri 3 Mataram. Populasi penelitian ini adalah seluruh siswa kelas VII MTs Negeri 3 Mataram yang berjumlah 90 siswa yang terbagi atas 3 kelas. Sedangkan sampel penelitian adalah siswa kelas VII A sebanyak 31 siswa sebagai kelas eksperimen dan siswa kelas VII B sebanyak 29 siswa sebagai kelas kontrol. Pengambilan sampel dilakukan dengan teknik simple random sampling. Teknik analisis data menggunakan uji-t polled varians. Data hasil belajar siswa diperoleh dari hasil tes awal dan tes akhir. Hasil tes awal diperoleh nilai rata-rata kelas untuk kelas eksperimen 41, sedangkan untuk kelas kontrol 44. Hasil tes akhir diperoleh nilai rata-rata kelas untuk kelas eksperimen 74 sedangkan untuk kelas kontrol 64. Berdasarkan hasil uji hipotesis diperoleh thitung sebesar 3,021 sedangkan tabel sebesar 1,696 pada taraf signifikan $5 \%$. Karena thitung lebih besar dari pada tabel maka dapat disimpulkan bahwa terdapat pengaruh penggunaan alat peraga berbantukan kearifan lokal terhadap hasil belajar fisika siswa kelas VII MTs Negeri 3 Mataram.
\end{abstract}

Kata Kunci : Pengaruh Penggunaan Alat Peraga, Berbantukan Kearifan Lokal, Peningkatan Hasil Belajar

PENDAHULUAN

Salah satu upaya pemerintah yang ditempuh guna meningkatkan mutu pendidikan adalah penyempurnaan kurikulum. Kurikulum 2013 merupakan penyempurnaan dari kurikulum 2006 atau lebih dikenal dengan KTSP. Kurikulum 2013 terdapat beberapa perubahan pada proses pembelajaran dan dalam proses penilaian. Pada kurikulum 2013 juga disebutkan tentang mata pelajaran IPA diajarkan secara terpadu sebagai mata pelajaran integrative science, bukan sebagai pendidikan disiplin ilmu (Kemendikbud, 2012). Proses belajar mengajar merupakan proses yang terpenting karena dari sinilah terjadi interaksi langsung antara pendidik dan salah satu penyebab yang umum adalah masih rendahnya prestasi belajar dalam mata pelajaran fisika.

dan perkembangan pengetahuan. Pembelajaran berbasis budaya lokal sebagai salah satu pembelajaran inovatif perlu terus dikembangkan. Integrasi budaya lokal dalam pembelajaran fisika menjadikan pembelajaran lebih bermakna bagi siswa (Supratman, dkk, 2016:82)
Fisika merupakan ilmu pengetahuan yang mempelajari berbagai fenomena alam. Dalam pembelajaran fisika yang berkualitas tidak lepas dari peran guru, dimana guru dituntut mampu menciptakan situasi pembelajaran yang aktif, kreatif, inovatif, efektif dan menyenangkan dalam proses pembelajaran khususnya pembelajaran fisika. Suasana dan lingkungan belajar yang kondusif untuk pembelajaran sains itu beragam, siswa akan lebih tepat jika mengoptimalkan kearifan lokal atau wilayah tertentu yang memiliki nilai kebudayaan, berkembang dalam lingkup lokal dari generasi ke generasi berikutnya. Pembelajaran berbasis budaya dilandaskan pada pengakuan terhadap budaya sebagai bagian yang fundamental bagi pendidikan sebagai ekspresi dari komunikasi suatu gagasan

Selain itu kearifan lokal sebagai salah satu hal yang perlu dilestarikan, artinya perlu dijaga, dilindungi, dan dilestarikan agar tidak punah. Berdasarkan hasil observasi atau pada saat Praktik Pengalaman Lapangan (PPL) di MTs Negeri 3 Mataram pada bulan Agustus sampai dengan bulan September 2016, diperoleh bahwa 
pemanfaatan lingkungan kurang optimal di dalam pembelajaran IPA dan media lingkungan hanya untuk meteri tertentu saja. Lingkungan hanya sebagai objek dalam pembelajaran tanpa mengetahui nilai-nilai budaya yang terkandung dalam pembelajaran IPA. Selain itu hasil wawancara dengan guru IPA MTs Negeri 3 Mataram diketahui bahwa alat peraga sebagai sumber belajar belum berjalan sesuai dengan harapan. Sehingga pada akhirnya prestasi belajar siswa menjadi rendah. Hasil prestasi belajar siswa yang rendah ditunjukkan dalam Tabel 1.

Tabel 1. Nilai Rata-Rata Siswa Mata Pelajaran Fisika Tahun Pelajaran 2015/2016 semester 1

\begin{tabular}{|c|c|c|}
\hline Kelas & Jumlah Siswa & Nilai Rata-rata \\
\hline $\mathrm{VII}_{\mathrm{A}}$ & 30 & 54.00 \\
\hline $\mathrm{V} \mathrm{II}_{\mathrm{B}}$ & 31 & 53.03 \\
\hline $\mathrm{V} \mathrm{II}_{\mathrm{C}}$ & 31 & 53.54 \\
\hline $\mathrm{V} \mathrm{II}_{\mathrm{D}}$ & 26 & 50.53 \\
\hline VIII & 21 & 54.45 \\
\hline
\end{tabular}

(Sumber: Arsip Guru Nilai IPA Rata-Rata Rapor Kelas)

Berdasarkan Tabel 1 di atas, maka dapat dilihat hasil belajar masih rendah. Hal ini dikarenakan kekurangan pemahaman pada mata pembelajaran fisika, sementara sumber belajar yang ada di sekitar lingkungan sekolah terabaikan begitu saja. Selain pemanfaatan sumber belajar yang kurang di dalam pembelajaran IPA, masalah lain yang dirasakan guru IPA MTs Negeri 3 Mataram yaitu belum optimalnya memanfaatkan fasilitas sekolah yang ada. Padahal salah satu kompetensi guru yaitu kompetensi professional dikatakan bahwa guru harus mampu mengembangkan materi pembelajaran dan media pembelajaran secara kreatif dengan memanfaatkan alat peraga agar lebih kreatif dalam menunjang kegiatan pembelajaran di sekolah. Salah satu upaya untuk mengatasi permasalahan tersebut, perlu dikembangkan media pembelajaran berupa alat peraga berbantukan kearifan lokal.

Alat peraga berbantukan kearifan lokal merupakan salah satu unsur penunjang pembelajaran agar tercipta pembelajaran yang efektif dengan memasukkan nilai-nilai budaya di dalamnya sehingga siswa tidak melupakan budayabudaya yang ada di suatu daerah tertentu. Oleh karena itu peneliti akan melakukan penelitian dengan judul pengaruh alat peraga berbantukan kearifan lokal terhadap hasil belajar fisika siswa kelas VII di MTs Negeri 3 Mataram.

\section{METODE PENELITIAN}

Berdasarkan pada permasalahan yang diteliti, metode yang digunakan dalam penelitian ini adalah metode deskriptif dengan pendekatan kuantitatif. Menurut Sugiyono, (2015:34) menjelaskan bahwa penelitian yang bersifat deskriptif merupakan penelitian yang memberi gambaran secermat mungkin mengenai suatu individu, keadaan, gejala atau kelompok tertentu.

Penelitian ini termasuk jenis penelitian eksperimen yang terdiri dari pemberian tes awal (pre-test) maupun tes akhir (post-test) baik kepada kelompok eksperimen maupun kelompok kontrol.

\section{Teknik Pengumpulan Data}

Dalam Riduwan (Nasir, 2003:328) mengatakan bahwa teknik pengumpulan data merupakan alat ukur yang di perlukan dalam melaksanakan suatu penelitian. Terdapat beberapa metode dalam pengumpulan data penelitian, berikut ini terdapat tiga cara untuk mengumpulkan berbagai informasi yang diperlukan peneliti, diantaranya adalah :

\section{Tes Hasil Belajar.}

Tes Arikunto (2006:53) tes merupakan alat atau prosedur yang digunakan mengetahui atau mengukur suatu dalam suasana, dengan cara dan aturan yang sudah-sudah ditentukan. Data tes yang dihasilkan rata-rata gain skor pretest dan posttes kemampuan hasil belajar.

Tes yang dibuat berupa pilihan ganda yang dilaksanakan sebelum dan sesudah diberikan. Tes bentuk pilihan ganda adalah sejenis tes kemampuan belajar yang memerlukan jawaban bersifat pilihan.

Soal yang digunakan pada tes awal sama dengan soal yang akan digunakan pada tes akhir. Hal ini yang dimaksud supaya tidak ada pengaruh perbedaan instrument terhadap hasil belajar fisika yang terjadi.

\section{Observasi}

Observasi adalah metode pengembangan terhadap sesuatu hal yang akan diteliti. Menurut Muri Yusuf, (2015:102) bahwa metode observasi adalah pengamatan yang diteliti dan sistematis tentang suatu obyek. Observasi ini di 
lakukan pada bulan Agustus sampai dengan bulan September 2017

\section{Dokumentasi}

Menurut Sugiyono, (2013:236) bahwa motode dokumentasi adalah cara mencari data dengan hal-hal atau variabel yang berupa data, catatan, transkip, buku-buku.

Variabel penelitian menurut Sugiyono (2015:60), "variabel pada dasarnya adalah segala sesuatu yang berbentuk apa saja yang ditetapkan oleh peneliti untuk dipelajari sehingga diperoleh informasi tentang hal tersebut, kemudian ditarik kesimpulannya." Peneliti ini membahas dua variabel, yakni variabel bebas dan variabel terikat, variabel bebas adalah variabel yang mempengaruhi atau yang menjadi sebab perubahannya atau timbulnya variabel terikat. Sedangkan variabel terikat adalah variabel yang dipengaruhi atau yang menjadi akibat, karena adanya variabel bebas. Dalam penelitian ini yang menjadi variabel bebas (X) adalah pemanfaatan alat peraga oleh siswa kelas VII MTs Negeri 3 Mataram dan yang menjadi variabel terikat $(\mathrm{Y})$ adalah peningkatan hasil belajar siswa pada mata pelajaran fisika.

Menurut Sugiyono (2012:148). Instrumen penelitian adalah suatu alat yang digunakan dalam kegiatan mengumpulkan data agar kegiatan tersebut menjadi sistematis dan dipermudah dalam melakukan penelitian. Sedangkan menurut Riduwan (2010:71). Instrument penelitian adalah seluruh alat pengambilan data yang digunakan dalam penelitian yang mencakup proses pengumpulan data dan tehnik penentuan kualitas (validitas dan reabilitas instrument penelitian).

\section{Instrumen Penelitian}

Instrumen penelitian adalah alat atau fasilitas yang digunakan oleh peneliti dalam mengumpulkan data agar pekerjaan lebih mudah dan hasilnya lebih baik, dalam arti lebih cermat, lengkap dan sistematik sehingga lebih mudah diolah (Arikunto 2006: 160). Instrumen yang digunakan dalam penelitian ini terdiri dari :

\section{Tes Awal (Pre Test)}

Tes kemampuan awal IPA fisika adalah untuk melihat kemampuan awal siswa dari masing-masing kelompok. Tes kemampuan awal diperoleh dari tes kemampuan siswa kelas VII-A (kontrol) dan VII-B (eksperimen).

Tes Hasil Belajar (post test)
Untuk melihat hasil belajar siswa, disusun alat ukur yang berbentuk tes obyektif dengan semua butir soal disusun berdasarkan materi yang di ajarkan selama eksperimen yaitu, disesuaikan dengan $\mathrm{K} 13$ yang berlaku saat penelitian berlangsung.

\section{Uji Coba Instrumen}

Sebelun instrumen tersebut digunakan, dalam penelitian terlebih dahulu diuji coba untuk mengetahui kelayakan instrumen dalam penelitian. Adapun instrumen yang diujicobakan adalah tes kognitif siswa.

Tujuan dari uji coba instrumen untuk mengetahui kualitas tes yang meliputi uji : (1) Validitas, (2) Reliabilitas, (3) Taraf kesukaran, (4) Daya pembeda.

Dari uraian di atas persyaratan yang harus dipenuhi agar tes dapat digunakan sebagai alat ukur yang baik adalah:

\section{Uji Validitas}

Butir soal dikatakan valid jika dapat mengukur secara tepat apa yang hendak diukur. Untuk mengetahui validitas butir soal digunakan teknik korelasi product moment dengan rumus sebagai beriku:

$$
r_{x y}=\frac{\mathrm{N} \sum \mathrm{XY}-\left(\sum \mathrm{X}\right)\left(\sum \mathrm{Y}\right)}{\sqrt{\left(\mathrm{N} \sum \mathrm{X}^{2}-\left(\sum \mathrm{X}\right)^{2}\right)\left(\mathrm{N} \sum \mathrm{Y}^{2}-\left(\sum \mathrm{Y}\right)^{2}\right.}}
$$

dengan :

$$
r_{x y}=\text { koefisien Korelasi }
$$

$\sum X=$ skor total item

$\sum Y=$ Skor item setiap responden

$\sum X Y=$ jumlah hasil kali skor per item dengan

$$
N \quad \text { = jumlah responden }
$$

Setelah diperoleh nilai kemudian dicocokkan dengan tabel $r$ product moment dengan interval kepercayaan 95\% jika $r_{\mathrm{xy}} \geq r_{\text {tabel }}$ maka soal tersebut dikatakan valid.

\section{Uji Reliabilitas}

Reliabilitas bertujuan untuk menentukan butir soal yang mempunyai taraf kepercayaan yang tinggi, dalam mengukur apa yang diukur. Rumus reliabilitas yang digunakan adalah K-R 20

$$
r_{11}=\left[\frac{k}{(k-1}\right]\left[\frac{S^{2}-\sum p q}{S^{2}}\right]
$$

Untuk mencari Varian total yaitu varian skor total $\left(S^{2}\right)$ adalah 


$$
S^{2}=\frac{\sum X t^{2}-\frac{\left(\sum X t\right)^{2}}{N}}{N}
$$

dengan:

$$
\begin{aligned}
& r_{11}=\text { koefisien korelasi internal seluruh } \\
& \text { item } \\
& k=\text { banyaknya item } \\
& \Sigma p q \quad=\text { jumlah hasil perkalian } p \text { dan } q \\
& p=\text { proporsi subjek yang menjawab } \\
& \text { item } \\
& \text { dengan benar } \\
& q \quad=\text { proporsi subjek yang menjawab } \\
& \text { item } \\
& \text { salah } \\
& S \quad=\text { standar deviasi ari tes } \\
& S^{2} \quad=\text { varian toal yaitu varian sekor total } \\
& \mathrm{X}_{\mathrm{t}} \quad=\text { sekor total item soal } \\
& \text { (Arikunto dalam Riduwan, } 2010 \text { : }
\end{aligned}
$$

$$
\text { Harga } r_{\text {hitung (nilai varians }}
$$

butir/varians total) yang diperoleh dikonsultasikan ke tabel harga kritik $r$ Product Moment. Pada taraf signifikan $5 \%$. Jika harga $r_{\text {hitung }}>r_{\text {tabel }}$ harga kritik Product Moment, maka harga $r_{\text {hitung }}$ (nilai varians butir/varians total) tersebut reliabel.

1 Uji Taraf Kesukaran

Tingkat kesukaran soal ditentukan berdasarkan banyak siswa yang menjawab soal dengan benar dibagi jumlah seluruh siswa peserta tes. Rumus yang digunakan adalah sebagai berikut :

$$
P=\frac{B}{J S}
$$

dengan :

$$
\begin{aligned}
& P \quad=\text { indeks kesukaran } \\
& B \quad=\text { banyak siswa yang menjawab } \\
& \text { soal dengan benar } \\
& \text { Js } \quad \text { jumlah seluruh siswa peserta tes } \\
& \text { (Arikunto, 2009:207- }
\end{aligned}
$$

Tabel 2. Kriteria Tingkat Kesukaran Butir

\begin{tabular}{|c|c|}
\multicolumn{1}{c}{ Nilai } & Keterangan \\
\hline 0,00 sampai 0,30 & Sukar \\
\hline 0,30 sampai 0,70 & Sedang \\
\hline 0,70 sampai 1,00 & Mudah \\
\hline
\end{tabular}

Uji Daya Pembeda

Daya pembeda butir soal bertujuan untuk mengukur sejauh mana butir soal tertentu mampu membedakan antara anak yang pandai dengan anak yang kurang pandai berdasarkan kriteria tertentu. Untuk menghitung digunakan rumus sebagai berikut :

$$
D P=\frac{B A}{J A}-\frac{B B}{J B}
$$

dengan :

$D P$ = daya Pembeda soal

$B A=$ banyak peserta kelompok atas yang menjawab soal dengan benar

$B B$ = banyak peserta kelompok bawah yang menjawab dengan benar

$J A=$ banyak peserta kelompok atas

$J B=$ banyak peserta kelompok bawah

Tabel 3. Kriteria Daya Beda

\begin{tabular}{|c|c|}
\hline Nilai & Keterangan \\
\hline $0,00-0,20$ & Jelek \\
\hline $0,21-0,40$ & Cukup \\
\hline $0,41-0,70$ & Baik \\
\hline $0,71-1,00$ & Baik sekali \\
\hline
\end{tabular}

\section{Prosedur Penelitian}

Untuk mengumpulkan data dalam penelitian eksperimen ini dilakukan melalui tahapan-tahapan sebagai berikut :

\section{Tahapan Persiapan}

Langkah pertama yang dilakukan adalah menyusun perangkat (RPP), tes awal (Pre-test), tes hasil belajar (post-test) sesuai dengan materi, silabus atau sesuai dengan Garis-Garis Besar Program Pelajaran (GBPP) SMP pada semester I, Pokok pembahasan tersebut diajarkan selama tiga jam pelajaran dengan 4 kali tatap muka. Selanjutnya melakukan uji coba instrumen hasil belajar IPA fisika kemudian dilanjutkan analisis instrument tersebut.

\section{Tahap Eksperimen}

Terlebih dahulu melakukan tes awal, kemudian dari hasil tersebut dilakukan eksperimen. Kelas eksperimen diajar dengan menggunakan alat peraga sedangkan kelas kontrol diajar dengan metode ceramah

\section{Tahap Akhir}

Setelah tahapan eksperimen dilakukan kemudian dilanjutkan dengan tahap akhir (post-test) untuk memperoleh data tes hasil belajar IPA fisika.

\section{HASIL DAN PEMBAHASAN}

Dalam penelitian ini menggunakan dua sampel yang merupakan keseluruhan dari anggota populasi dan dibagi menjadi kelas eksperimen dan kelas kontrol. Adanya 
kelas eksperimen bertujuan untuk mengetahui pengaruh alat peraga berbantukan kearifan lokal terhadap hasil belajar fisika siswa kelas VII MTs Negeri 3 Mataram pokok bahasan suhu dan kalor. Adanya kelas kontrol adalah sebagai kelas pembanding atau kelompok kontrol, sehingga akibat yang diperoleh dari perlakuan yang berbeda dari kedua kelompok ini dapat diketahui secara pasti antara kelas yang diberi perlakuan dengan menggunakan alat peraga berbantukan kearifan lokal dan kelas kontrol yang diberi perlakuan dengan menggunakan metode ceramah pada pokok bahasan yang sama yakni suhu dan kalor.

Dalam proses penelitian ini pula sebelum instrumen tes diberikan, terlebih dahulu dilakukan uji validitas item soal dengan menggunakan rumus product moment. untuk mengetahui apakah hasil perhitungan validitas butir soal sudah signifikan atau tidak, maka perlu dibandingkan dengan $r_{\text {tabel. Karena jumlah }}$ siswa untuk uji coba instrumen ini berjumlah 28 orang maka harga $r_{\text {tabel }}$ yang diperoleh sebesar 0,374 (dilihat dari tabel harga kritik $r$ product moment) pada taraf signifikasi $5 \%$. Jumlah soal instrumen ini sebanyak 30 soal dan diperoleh soal yang valid sebanyak 28 soal. Setelah itu dilakukan uji reliabilitas seluruh item soal dengan menggunakan rumus KR-20 dan diperoleh reliabilitasnya $\left(r_{11}=0,932\right)$. Hasil perhitungan reliabilitas tes yang diperoleh dibandingkan dengan $r_{\text {tabel. }}$. Karena jumlah soal instrumen yang diujikan sebanyak 30 soal dan jumlah siswa sebanyak 28 orang maka diperoleh $r_{\text {tabel }}$ sebesar 0,374 pada taraf signifikasi $5 \%$. Jadi dapat disimpulkan bahwa reliabilitas tes lebih besar dari $r_{\text {tabel }}(0,932 \geq 0,374)$ sehingga instrumen penelitian bersifat reliabel.

Dari tes awal (pre-test) diperoleh nilai rerata kelas eksperimen 40,43 dan kelas kontrol 36,49 kemudian dilakukan uji homogenitas sampel diperoleh $F_{\text {hitung }}=$ 1,436 dan $F_{\text {tabel }}=1,960$ pada taraf signifikan $5 \%$, berdasarkan kriteria pengujian jika $F_{\text {hitung }} \leqslant F_{\text {tabel }}$ maka sampel homogen. Dengan demikian dapat dikatakan bahwa kedua sampel yaitu kelas eksperimen dan kelas kontrol memiliki kemampuan yang homogen. Kemudian dilakukan uji normalitas untuk kelas eksperimen dan kelas kontrol, dan berdasarkan hasil perhitungan untuk kelas eksperimen diperoleh $\chi^{2}$ hitung $=5,54$ dan $\chi^{2}$ tabel 11,070 pada taraf signifikan $5 \%$. Dan untuk kelas kontrol diperoleh $\chi^{2}$ hitung

$=5,76$ dan $\chi^{2}$ tabel 11,070 pada taraf signifikan $5 \%$. Berdasarkan kriteria pengujian jika $x^{2}$ hitung $\leq \chi^{2}$ tabel maka data terdistribusi normal. Dengan demikian hasil pre-test kelas eksperimen dan kelas kontrol terdistribusi secara normal.

Sedangkan dari tes akhir (post-test) diperoleh nilai rerata kelas eksperimen 76,26 dan kelas kontrol 68,00 kemudian dilakukan uji homogenitas sampel diperoleh $F_{\text {hitung }}=2,06$ dan $F_{\text {tabel }}=1,63$ pada taraf signifikan $5 \%$, berdasarkan kriteria pengujian jika $F_{\text {hitung }} \geq F_{\text {tabel }}$ maka sampel tidak homogen. Dengan demikian dapat dikatakan bahwa kedua sampel yaitu kelas eksperimen dan kelas kontrol memiliki kemampuan yang heterogen. Kemudian dilakukan uji normalitas untuk kelas eksperimen dan kelas kontrol, dan berdasarkan hasil perhitungan untuk kelas eksperimen diperoleh $x^{2}$ hitung $=10,02$ dan $x^{2}$ tabel $=11,07$ pada taraf signifikan $5 \%$. Dan untuk kelas kontrol diperoleh $x^{2}$ hitung $=11,04$ dan $x^{2}$ tabel $=11,07$ pada taraf signifikan $5 \%$. Berdasarkan kriteria pengujian jika $x^{2}$ hitung $\leq$ $x^{2}$ tabel maka data terdistribusi normal. Dengan demikian hasil post-test kelas eksperimen dan kelas kontrol terdistribusi secara normal. Selanjutnya data hasil posttest digunakan untuk perhitungan uji hipotesis dan diperoleh nilai $t_{\text {hitung }}=3,93$ sedangkan $t_{\text {tabel }}=2,00$ pada taraf signifikan $5 \%$. Berdasarkan kriteria pengujian jika $t_{\text {hitung }}$ $>$ tabel maka Ha diterima sedangkan Ho ditolak.

Berdasarkan nilai rata-rata yang diperoleh ternyata kelas eksperimen yang mendapat pengajaran dengan menggunakan alat peraga berbantukan kearifan lokal lebih tinggi dibandingkan dengan kelas kontrol yang mendapat pengajaran dengan menggunakan metode ceramah. Di mana nilai rata-rata pre-test kelas kontrol sebesar 36,49 dan setelah mendapat pengajaran menggunakan metode ceramah meningkat menjadi 68,00 dengan ketuntasan klasikal $80 \%$, sedangkan 
nilai rata-rata pre-test untuk kelas eksperimen sebesar 40,43 dan setelah mendapat pengajaran dengan menggunakan alat peraga berbantukan kearifan lokal meningkat menjadi 76,26 dengan ketuntasan klasikal $87 \%$. Ini berarti bahwa ada pengaruh alat peraga berbantukan kearifan lokal terhadap hasil belajar fisika siswa kelas VII MTs Negeri 3 Mataram pokok bahasan suhu dan kalor. Peningkatan hasil belajar ini disebabkan karena menggunakan alat peraga berbantukan kearifan lokal merupakan suatu model pembelajaran yang menekankan pada tiga aspek yaitu Auditory, Intellectualy, dan Repatition. Di mana pada aspek Auditory siswa belajar dengan cara mendengarkan penyajian materi dari guru, menyimak penjelasan yang dipaparkan oleh guru, berbicara sesama anggota kelompoknya untuk berdiskusi menyelesaikan tugas yang diberikan, kemudian mempersentasikan hasil jawaban kelompoknya, kelompok yang lain menanggapi dengan memberikan pertanyaan-pertanyaan, siswa mengemukakan pendapatnya dan siswa yang lain menanggapi pendapat temannya yang kurang tepat, sehingga hal ini cenderung membuat siswa lebih aktif dalam proses pembelajaran.

Pada aspek Intellectualy siswa saling membantu dalam memahami materi yang dipelajari, saling bertukar pikiran sehingga seluruh siswa dapat memahami materi yang sudah diajarkan. Sedangkan pada aspek Repatition guru memberikan pengulangan, memberi penjelasan dan penegasan terhadap point penting dari inti materi yang diajarkan sesuai dengan tujuan pembelajaran yang ingin dicapai dengan cara memberikan kesimpulan pada akhir pelajaran dan memberikan tugas atau kuis.

Sebagaimana yang telah dipaparkan di atas merupakan alat peraga yang menekankan pada tiga komponen yaitu. Auditory yang meliputi mendengar, menyimak, bebicara, argumentasi, mengemukakan pendapat. Intellectualy meliputi kegiatan bernalar, memecahkan masalah dan menerapkan. Repatition yaitu pengulangan melalui pengerjaan soal dan pemberian tugas. Akibat dari penekanan pada tiga komponen ini siswa memiliki kemampuan memahami dan memcahkan masalah yang lebih baik, memiliki daya ingat yang kuat serta kreatif dan aktif

Pada kelas kontrol, siswa diajarkan menggunakan metode ceramah. Proses pembelajaran pada kelas kontrol sama seperti yang dilakukan oleh guru sebelumnya tidak melibatkan siswa secara langsung untuk berdiskusi dan bertukar pikiran. pada kelas kontrol peneliti tidak mengalami kesulitan menerapkan metode ceramah karena siswa sudah terbiasa dengan cara mengajar guru sebelumnya yang menempatkan siswa dalam suasana yang monoton, kurang adanya interaksi antar guru dengan siswa dan antar siswa dengan siswa lainnya sehingga siswa-siswa yang mengalami kesulitan memahami materi yang diajarkan tidak dapat dibantu oleh teman-temannya yang sudah memahami, akibatnya siswa cenderung menyelesaikan soal secara individu yang mengakibatkan niali rata-rata hasil post test pada kelas kontrol lebih rendah dibandingkan dengan kelas eksperimen.

Dengan demikian dapat dikatakan bahwa ada pengaruh alat peraga berbantukan kearifan lokal terhadap hasil belajar fisika siswa kelas VII MTs Negeri 3 Mataram pokok bahasan suhu dan kalor. Hal ini membuktikan bahwa penggunaan alat peraga berbantukan kearifan yang bervariasi dapat menjadi motivasi bagi siswa dalam kegiatan belajar mengajar sehingga dapat meningkatkan hasil belajar IPA fisika siswa.

\section{KESIMPULAN}

Berdasarkan rumusan masalah dan tujuan penelitian dapat disimpulkan bahwa ada pengaruh yang signifikan sebesar $5 \%$, sehingga pengajaran menggunakan alat peraga berbantukan kearifan lokal dan lebih efektif untuk meningkatkat hasil belajar fisika siswa pada pokok bahasan suhu dan kalor yang diajarkan pada siswa kelas VII semester ganjil MTs Negeri 3 Mataram, adapun rata-rata post test untuk kelas kontrol 68,00 dengan ketuntasan belajar mencapai $80 \%$, dan rata-rata post test untuk kelas eksperimen 76,26 dengan ketuntasan belajar mencapai $87 \%$.

DAFTAR PUSTAKA

Arikunto, Suharsimi, 2013. Dasar-Dasar Evaluasi Pendidikan. Jakarta: Bumi Aksara 
Arsyad, Azhar, 2015. Media Pembelajaran. Depok: PT Rajagrafindo Persada

Azizahwati, dkk. Pengembangan Modul Pembelajaran Fisika SMA Berbasis Kearifan Lokal untuk Meningkatkan Hasil Belajar Siswa. Jurnal Prosiding Pertemuan IImiah XXIX HFI. ISSN : 0853-0823

Baiq Ewik Jiniarti, dkk. Implementasi Model Problem Based Learning Berbantuan Alat Peraga Untuk Meningkatkan Aktivitas dan Hasil Belajar Fisika Siswa Kelas VIII SMPN 22 Mataram Tahun Pelajaran 2014/2015. Jurnal Pendidikan Fisika dan Teknologi Volume I No 3 ISSN. 2407-6902

Daryanto, 2015. Media Pembelajaran. Bandung: PT. Sarana Tutorial Nurani Sejahtera

Dian Hardianti, dkk. Perbedaan Hasil Belajar Fisika Siswa Untuk Model Pembelajaran Berbasis Proyek Dengan Model Pembelajaran Langsung Pada Kelas X SMA Negeri 7 Palu. Jurnal Pendidikan Fisika Tadulako (JPFT) Vol. 4 No. 2. ISSN 23383240 E-Jurnal Dinas Pendidikan Kota Surabaya; Volume 5 ISSN : 2337-3253

Giancoli, 2001. Fisika Edisi Kelima Jilid 1. Jakarta: PT. Gelora Aksara Pratama

Halliday David, 2003. Dasar-Dasar Fisika jilid I. Tanggerang: Binarupa Aksara Publisher.

Islahudin, I., Darmayanti, N.W.S., Zulkarnain, Z, (2017). Pengaruh Pemanfaatan Alat Peraga Berbasis Kearifan Lokal Terhadap Peningkatan Hasil Belajar Fisika Pada Siswa Kelas VIII Di MTs Nurul Iman NW Kembang Kerang Lombok Tengah Tahun Pelajaran 2017/2018. ORBITA : Jurnal Kajian, Inovasi dan Aplikasi Pendidikan Fisika, 3(2), 46-52.

Riduwan, 2014. Metode dan Teknik Menyusun Proposal Penelitian. Bandung: Alvebeta. Cv

Sudjana, Nana, 2014. Penelitian dan Penilaian Pendidikan. Bandung: Sinar Baru Algensindo

Sugiyono, 2013. Metode Penelitian Pendidikan Pendekatan Kuantitatif, Kualitatif dan $R \& D$. Bandung: Alvabeta. Cv

Sugiyono, 2015. Metode Penelitian Pendidikan Pendekatan Kuantitatif, Kualitatif dan $R \& D$. Bandung: Alvabeta. Cv

Suherman, dkk. IbM Perangkat Pembelajaran Berbasis Budaya Sunda Untuk GuruGuru Mipa Smp Di Kecamatan Karangnunggal Tasikmalaya. Jurnal Siliwonsi Vol.2 No.1. ISSN 2477-6629

Yusuf, Muri, 2015. Asesmen Dan Evaluasi Pendidikan. Jakarta: Prenadamedia Group. 